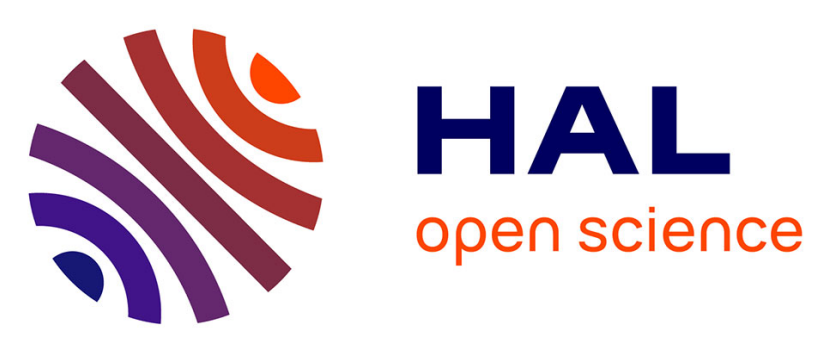

\title{
Transport of Multicomponent Hydrocarbon Mixtures in Shale Organic Matter by Molecular Simulations
}

\author{
Julien Collell, Guillaume Galliero, Romain Vermorel, Philippe Ungerer,
} Marianna Yiannourakou, François Montel, Magali Pujol, François Gelin

\section{To cite this version:}

Julien Collell, Guillaume Galliero, Romain Vermorel, Philippe Ungerer, Marianna Yiannourakou, et al.. Transport of Multicomponent Hydrocarbon Mixtures in Shale Organic Matter by Molecular Simulations. 13èmes Journéess d'études des Milieux Poreux 2016, Oct 2016, Anglet, France. hal01394503

\section{HAL Id: hal-01394503 \\ https://hal.science/hal-01394503}

Submitted on 9 Nov 2016

HAL is a multi-disciplinary open access archive for the deposit and dissemination of scientific research documents, whether they are published or not. The documents may come from teaching and research institutions in France or abroad, or from public or private research centers.
L'archive ouverte pluridisciplinaire HAL, est destinée au dépôt et à la diffusion de documents scientifiques de niveau recherche, publiés ou non, émanant des établissements d'enseignement et de recherche français ou étrangers, des laboratoires publics ou privés. 


\title{
Transport of Multicomponent Hydrocarbon Mixtures in Shale Organic Matter by Molecular Simulations
}

\author{
Julien Collell1 ${ }^{1}$, Guillaume Galliéro², Romain Vermorel$^{2}$, Philippe Ungerer ${ }^{3}$, Marianna Yiannourakou ${ }^{3}$, \\ François Montel ${ }^{1}$, Magali Pujol ${ }^{1}$ and François Gelin ${ }^{1}$. \\ ${ }^{1}$ Total S A, Centre Scientifique et Technique Jean-Féger, Avenue Larribeau, 64018 Pau, France \\ ${ }^{2}$ Laboratory of Complex Fluids and their Reservoirs, UMR-5150 CNRS - Total - University of Pau, 64000 Pau, France \\ ${ }^{3}$ Materials Design SARL, 18 rue de Saisset, 92120 Montrouge, France \\ *Corresponding/Presenting author: julien.collell@,total.com
}

Keywords: Multicomponent Transport, Nanoporous Membrane, Molecular Simulations, Modeling

\section{Abstract}

Hydrocarbon production from shales has significantly increased in the past years. However, the recovery process remains largely unknown, which hinders the sustainability of such resources. In particular, hydrocarbons in shales are mostly located in microporous nodules of organic matter, the so-called kerogen, which are likely to act as selective barriers to hydrocarbon flow [1].

In this work, hydrocarbon transport properties through microporous kerogen membranes [2] were investigated by the means of molecular simulations. To do so, Boundary-Driven Non Equilibrium Molecular Dynamic (BD-NEMD) [3] simulations (see figure 1) have been performed to study the mechanisms of pure fluids transport through kerogen porous structure.

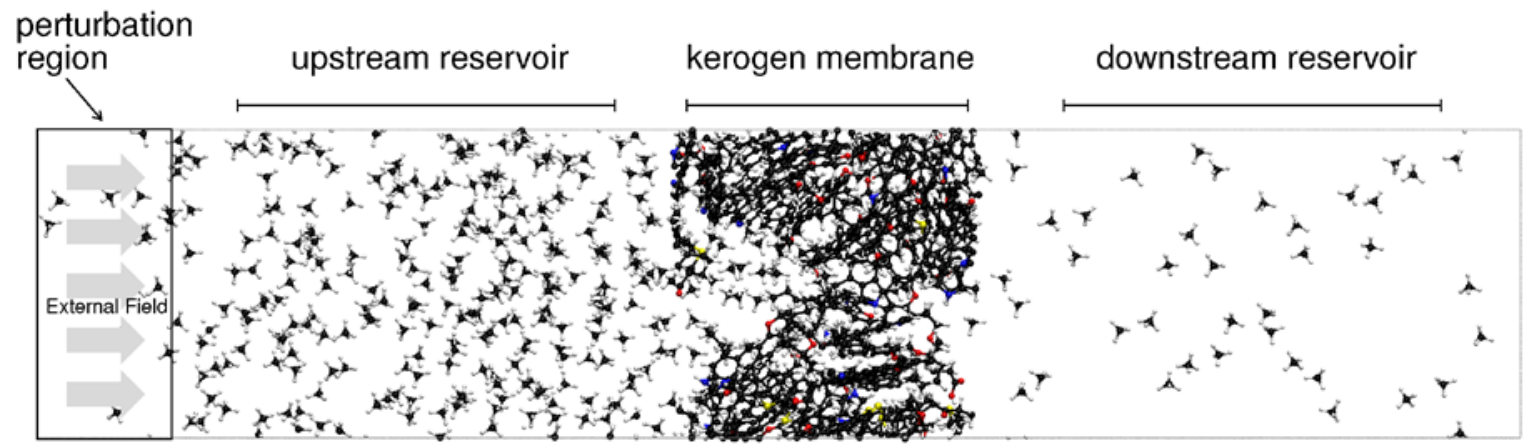

Figure 1: Schematic representation of NEMD algorithm used in this work. Kerogen membrane is immersed within two fluid reservoirs. A pressure difference is generated between the two reservoirs, thanks to an external field applied in the so-called perturbation region, which results in a fluid flow within the kerogen membrane.

By expressing the one-dimensional mass flux across the porous structure as a function of chemical potential gradient, mass transfer coefficient $\left(\chi_{t}^{0}\right)$ through the kerogen membrane has been determined. These mass transfer coefficients were compared to Maxwell-Stefan diffusivities $(D)$, obtained from Equilibrium Molecular Dynamic (EMD) simulations. Within uncertainties, these two coefficients are equals. As an illustration, in figure 2 are presented the results obtained for pure methane and pure carbon dioxide. Thus, our results show that hydrocarbon transport within kerogen is essentially caused by a diffusion process. In addition, it has been found that Maxwell-Stefan diffusivities could be well approximated by the self-diffusivities, which could be obtained experimentally. 


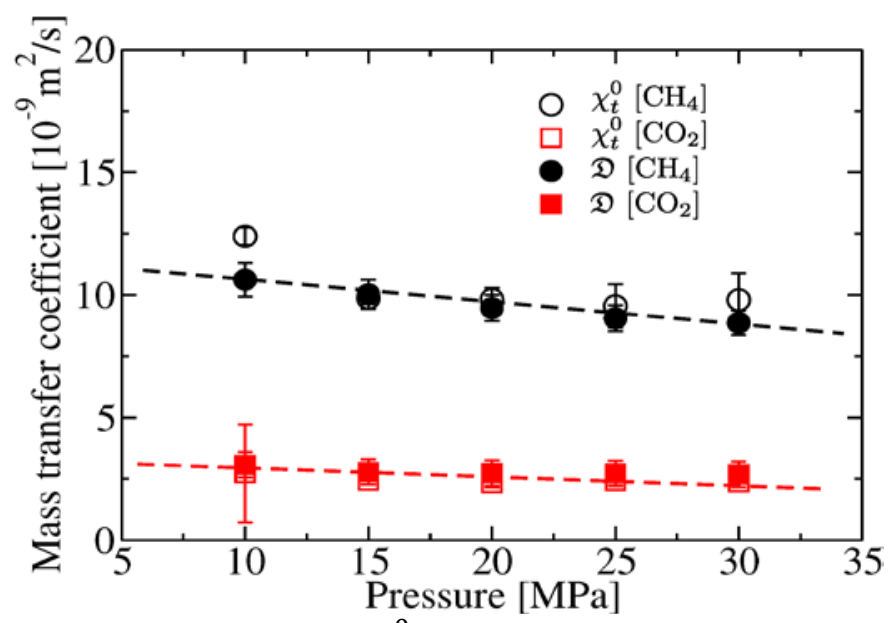

Figure 2: Comparison of mass transfer coefficients $\chi_{t}^{0}$ with Maxwell-Stefan diffusivities $D$ obtained on pure methane and carbon dioxide, as a function of the average reservoir pressure.

Based on these observations, linear hydrocarbon (n-alkane) diffusion was investigated. The impact of hydrocarbon chain length and the thermodynamic conditions (temperature and adsorbed amount) was quantified and modeled.

Then, from the conclusions drawn on pure compounds, diffusion of binary and ternary hydrocarbon mixtures, as well as a realistic reservoir fluid mimicking a typical condensate gas [2] has been studied. The Onsager's matrix, characterizing the diffusive flux, has been quantified. This matrix is dominated by its diagonal coefficients, whereas Onsager's cross-correlation coefficients are negligible. This indicates that diffusive fluxes induced by interspecies friction are negligible compared to the diffusive fluxes induced by friction with the porous structure. Such behavior can be explained by the important confinement of the fluid species, within the kerogen micropores. Finally, inspired by the Rouse and surface diffusion theories, we propose a simple scaling law that predicts the transport coefficients of linear alkanes in the mixture in good agreement with our simulations data [4].

\section{References}

[1] Falk, K.; Coasne, B.; Pellenq, R.; Ulm, F.; Bocquet, L. Subcontinuum mass transport of condensed hydrocarbons in nanoporous media. Nat. Commun., 1-25 (2015).

[2] Collell, J.; Ungerer, P.; Galliero, G.; Yiannourakou, M.; Montel, F.; Pujol, M. Molecular Simulation of Bulk Organic Matter in Type II Shales in the Middle of the Oil Formation Window. Energy \& Fuels, 28, 7457-7466 (2014).

[3] Frentrup, H.; Avendano, C.; Horsch, M.; Salih, A.; Muller, E. A. Transport diffusivities of fluids in nanopores by nonequilibrium molecular dynamics simulation. Mol. Simul., 38, 540-553 (2012).

[4] Collell, J.; Galliéro, G.; Vermorel, R.; Ungerer, P.; Yiannourakou, M.; Montel, F.; Pujol, M. Transport of Multicomponent Hydrocarbon Mixtures in Shales Organic Matter by Molecular Simulations. J. Phys. Chem. C, 119(39), 22587-22595 (2015). 